\title{
KARAKTERISASI TES KETERAMPILAN PEMECAHAN MASALAH FISIKA BERDASARKAN TEORI RESPONS BUTIR
}

\author{
S. Mulyani ${ }^{1 *}$, R. Efendi ${ }^{2}$, T. R. Ramalis ${ }^{3}$ \\ ${ }^{1}$ SMAI Cipasung, Singaparna, Tasikmalaya \\ Komplek Pondok Pesantren Cipasung Tasikmalaya 46417, Indonesia \\ E-mail : mulyanisri940@gmail.com \\ ${ }^{2}$ Program Studi Pendidikan Fisika, Fakultas Matematika dan Ilmu Pengetahuan Alam \\ Universitas Pendidikan Indonesia (UPI) \\ Jalan Dr Setiabudhi No. 229 Bandung 40154, Indonesia \\ ${ }^{3}$ Program Studi Pendidikan Fisika, Fakultas Matematika dan Ilmu Pengetahuan Alam \\ Universitas Pendidikan Indonesia (UPI) \\ Jalan Dr Setiabudhi No. 229 Bandung 40154, Indonesia
}

\begin{abstract}
Abstrak
Penelitian ini bertujuan untuk mengarakterisasi tes keterampilan pemecahan masalah Fisika berdasarkan teori respons butir. Metode dan desain penelitian yang digunakan dalam penelitian ini adalah metode penelitian dan pengembangan dengan desain penelitian konstruksi dan validasi, instrumen yang dibuat peneliti didasarkan pada lima indikator yang merujuk pada tahapan strategi keterampilan pemecahan masalah pada Robust Assessment Instrument For Student Problem Solving yang dikembangkan oleh Doctor dan Heller. Partisipan dalam penelitian ini yaitu siswa SMA Kelas XI. Hasil analisis dari kurva karakteristik tes dengan menggunakan teori respons butir menunjukkan bahwa tes memiliki parameter tingkat kesukaran (b) yang termasuk dalam kategori sedang, dan daya pembeda (a) dengan kategori tes memiliki parameter daya pembeda (a) yang baik. Secara umum interpretasi dari tes yang dikonstruksi dapat menilai keterampilan pemecahan masalah siswa dengan kemampuan rendah hingga sangat tinggi.
\end{abstract}

Kata kunci: keterampilan pemecahan masalah, konstruksi dan validasi, teori respons butir

\section{PENDAHULUAN}

Keterampilan pemecahan masalah merupakan salah satu keterampilan atau kompetensi yang harus dikuasai oleh seseorang pada Abad 21, sebagaimana yang telah dirumuskan oleh Assessment and Teaching of 21st Century Skills (ATC21S) yang mengategorikan keterampilan abad ke-21 menjadi 4 kategori, yaitu cara berpikir, cara bekerja, dan keterampilan untuk bekerja dan hidup di dunia (Binkley, 2012 ; Barak, 2017). Adapun kelompok keterampilan cara berpikir mencakup kreativitas, inovasi, berpikir kritis, memecahkan masalah, dan pembuatan keputusan. Kehidupan di abad 21 menuntut berbagai keterampilan yang harus dikuasai seseorang, sehingga diharapkan pendidikan dapat mempersiapkan siswa untuk menguasai berbagai keterampilan tersebut agar menjadi pribadi yang sukses dalam hidup (Zubaidah, 2016). Hal ini menjadi tantangan bagi para pendidik khususnya dibidang sains untuk memfasilitasi para siswa agar memiliki berbagai keterampilan tersebut disamping mengajarkan materi pembelajaran yang harus dikuasai oleh para siswa. Kemampuan yang penting dimiliki oleh siswa ini dapat mendorong siswa untuk menyusun sendiri teorinya (their own theories), mengujinya, menguji teori temannya, membuangnya jika teori tersebut tidak 
konsisten dan mencoba yang lainnya (Chrisnawati 2007). Kemampuan pemecahan masalah ini diperlukan supaya siswa mampu bersaing secara global di abad ini (Dewi, Poedjiastoeti, Prahani, 2017).

Dunia pendidikan sendiri mengharuskan pendidik untuk melakukan sebuah evaluasi untuk mengetahui keterampilan pemecahan masalah yang dimiliki oleh siswa. Evaluasi dalam pendidikan salah satunya dapat menggunakan tes yang berfungsi untuk memberikan informasi mengenai aspek tertentu (Retnawati, 2014), dengan menggunakan tes, selain untuk mendapatkan informasi mengenai keterampilan pemecahan masalah siswa, dapat juga meningkatkan keterampilan pemecahan masalah. Hidayat et al. (2017) menyebutkan bahwa keterampilan pemecahan masalah siswa juga perlu diukur dengan tujuan untuk mengetahui bagaimana kesiapan siswa dalam menghadapi tantangan abad 21.

Analisis butir soal diperlukan dalam proses pembuatan tes dengan tujuan untuk mengetahui mutu soal sehingga dapat memberikan informasi mengenai karakterisasi dari butir tes tersebut ataupun analisis empiris (Sarea \& Hadi, 2015). Adapun untuk menganalisis butir soal tersebut dapat digunakan Item Response Theory (IRT). IRT merupakan teori analisis butir soal yang termasuk kedalam teori analisis modern. Teori analisis butir soal modern ini dikembangkan oleh para ahli untuk mengatasi kekurangan-kekurangan yang ada pada teori analisis butir klasik, sehingga dapat dikatakan bahwa model IRT ini berupa teori respons butir sebagai penyempurna teori analisis butir klasik (Classical Test Theory).

Salah satu kekurangan dari analisis butir klasik dijelaskan oleh Setiadi (1998) bahwa dalam teori klasik, statistik soal, misalnya indeks kesukaran soal tergantung pada sampel pengikut ujian, jika soal dikerjakan oleh siswa yang pandai maka karakter soal akan menjadi mudah begitu pun jika soal dikerjakan oleh siswa yang kurang pandai maka tingkat kesukaran akan menjadi sukar. Hal ini menyebabkan ketidakkonsistenan tingkat kesukaran dari soal. Pada penskoran klasik menurut Sudaryono (2011) ada keterkaitan antara kedua kelompok butir tes dan kelompok peserta tes yang memungkinkan munculnya beberapa hal: 1) kelompok peserta uji tes yang cirinya diskor perlu mengikuti tes yang sama pada saat yang bersamaan, sehingga perlu dihindari kebocoran butir tes sebelum tes dilaksanakan; 2) keterkaitan antara kelompok butir dan kelompok peserta tes mengakibatkan tafsiran skor diarahkan pada kelompok peserta tes yang menjawab tes tersebut. Biasanya tafsiran tersebut mengacu ke acuan norma; dan 3) tes yang terlalu mudah atau terlalu sukar tidak akan mencerminkan kemampuan peserta tersebut dengan akurat, sehingga kedua bentuk tes tersebut dipertimbangkan untuk diganti.

Item respons theory (IRT) merupakan perbaikan dari kelemahan yang ada pada teori klasik. Kelebihan dari IRT yaitu salah satunya adalah menekankan pada tingkat butir soal bukan tes (Hambleton \& Jones, 1993). Proses tersebut disebut dengan invariansi di antara butir tes dan peserta tes (Sudaryono, 2011), pada pengukuran modern, taraf sukar butir tidak dikaitkan langsung dengan kemampuan responden.

Berdasarkan latar belakang tersebut, penelitian ini bertujuan untuk mengarakterisasi tes yang dapat mengukur tingkat keterampilan pemecahan masalah siswa SMA pada bidang Fisika khususnya pada materi Dinamika Rotasi dan Kesetimbangan Benda Tegar menggunakan analisis teori respons butir sebagai alat analisis Karakterisasi tes.

\section{METODOLOGI}

Penelitian ini menggunakan metode penelitian dan pengembangan dengan desain penelitian konstruksi dan validasi yang merujuk pada Crocker, Linda, \& Algina (1986). Pada tahap konstruksi terdiri dari beberapa tahap seperti mengidentifikasi kegunaan tes, mengidentifikasi karakter tes, mempersiapkan spesifikasi tes, dan mengonstruksi butir soal; sedangkan pada tahap validasi terdiri dari tahap uji pendahuluan, uji lapangan skala besar, menentukan skor butir, dan menganalisis hasil tes dengan menggunakan IRT. Partisipan dalam penelitian ini adalah 171 orang siswa SMA kelas XI yang telah mempelajari materi Dinamika Rotasi dan Kesetimbangan Benda Tegar. Partisipan penelitian dipilih secara purposive sampling, dalam hal ini adalah siswa pada tingkat sekolah menengah atas yang telah mempelajari materi Dinamika Rotasi dan Kesetimbangan Benda Tegar dan pemilihan kelas didasarkan atas rekomendasi dari guru fisika di sekolah 
partisipan. Selain itu sekolah yang dijadikan penelitian merupakan sekolah yang sudah menerapkan kurikulum 2013. Instrumen penelitian yang digunakan dalam penelitian ini diantaranya adalah pedoman wawancara kognitif, lembar judgement instrumen, dan instrumen tes keterampilan pemecahan masalah.

Pedoman wawancara kognitif digunakan peneliti dalam tahap uji pendahuluan (uji terbatas). Tujuan dilakukan wawancara kognitif adalah untuk mengumpulkan informasi mengenai respons atau tanggapan dari peserta tes terhadap instrumen yang diuji cobakan seperti keterbacaan, dan tata bahasa dari setiap butir soal untuk selanjutnya dijadikan acuan sebagai bahan perbaikan terhadap pengembangan tes keterampilan pemecahan masalah yang dikonstruksi.

Lembar judgement instrumen digunakan sebagai lembar penilaian (judgement) oleh para ahli (validator) yang digunakan untuk mengukur seberapa valid instrumen yang telah dibuat. Aspek yang dinilai dalam lembar penilaian instrumen yaitu kesesuaian soal dengan dimensi keterampilan pemecahan masalah, ketepatan soal mengukur indikator dimensi, ketepatan soal mengukur indikator soal, dan kejelasan kata/penyusunan kata pada soal agar butir soal yang diujikan merupakan perangkat tes yang representatif untuk menilai keterampilan pemecahan masalah.

Tes keterampilan pemecahan masalah yang dijadikan instrumen dalam penelitian ini adalah tes keterampilan pemecahan masalah yang dibuat oleh peneliti. Bentuk tes keterampilan pemecahan masalah yang digunakan berupa tes tertulis uraian (essay). Setiap butir soal mengacu pada tahapan strategi keterampilan pemecahan masalah yang dikembangkan oleh Doctor dan Heller (2009).

\section{HASIL DAN PEMBAHASAN \\ 3.1 Tahap Konstruksi}

Pada tahap ini peneliti mengidentifikasi bahwa tes yang di konstruksi bertujuan untuk mengukur tes keterampilan pemecahan masalah siswa. Instrumen tes tersebut didasarkan pada indikator yang sesuai dengan aspek-aspek keterampilan pemecahan masalah pada Robust Assessment Instrument for Student Problem Solving yang telah dikembangkan oleh Doctor dan Heller (2009). Adapun aspek keterampilan pemecahan masalah tersebut antara lain: memfokuskan permasalahan (visualize the problem), mendeskripsikan masalah dalam konsep fisika (describe the problem in physics description), merencanakan solusi melalui aplikasi khusus konsep fisika (plan the solution), melaksanakan rencana pemecahan masalah berdasarkan prosedur matematika (execute the plan), dan mengevaluasi solusi dengan kesimpulan logis (check and evaluate).

Selain menentukan aspek dan indikator keterampilan pemecahan masalah, peneliti juga memperhatikan tes yang dibuat berdasarkan materi ajar. Dari segi materi, soal atau tes mengenai dinamika rotasi dan kesetimbangan benda tegar harus disesuaikan dengan pembelajaran yang berlangsung di sekolah, hal ini karena pada akhirnya soal akan diuji cobakan kepada siswa yang telah mempelajari materi tersebut. Agar soal sesuai dengan pembelajaran di sekolah, maka peneliti diharuskan untuk memperhatikan silabus mata pelajaran Fisika SMA yang dikeluarkan oleh Kementerian Pendidikan dan Kebudayaan Republik Indonesia pada tahun 2016.

Berdasarkan silabus tersebut, tes mengenai dinamika rotasi dan kesetimbangan benda tegar mencakup materi momen gaya, momen inersia, keseimbangan benda tegar, titik berat, dan hukum kekekalan momentum sudut pada gerak rotasi. Soal yang dikonstruksi pada penelitian ini berupa 4 nomor (empat) soal uraian (essay) yang terdiri dari 20 poin soal dengan 20 indikator yang disesuaikan dengan sub materi pada materi Dinamika rotasi dan Kesetimbangan benda tegar.

\subsection{Tahap Validasi}

Pada tahap validasi ini dilakukan proses review soal atau penelaahan terhadap kelayakan instrumen tes (soal) yang dibuat dengan meminta bantuan terhadap para ahli dibidangnya. Penelaahan (review) soal ini dilakukan 
oleh 5 orang validator yaitu dosen Pendidikan Fisika Universitas Pendidikan Indonesia. Para ahli melakukan pengoreksian baik secara struktur kalimat (bahasa) maupun konsep materi yang disajikan pada tes tersebut. Hasil validasi ahli kemudian dianalisis dengan menggunakan analisis Aiken'V (Aiken, 1985). Hasil analisis seperti pada tabel di bawah ini :

Tabel 1. Analisis Aiken untuk Aspek Materi

\begin{tabular}{|c|l|c|}
\hline \multirow{2}{*}{$\begin{array}{c}\text { Butir } \\
\mathrm{Ke}-\end{array}$} & $\begin{array}{l}\text { Kesesuaian } \\
\text { dengan } \\
\text { kompetensi } \\
\text { yang ingin } \\
\text { dicapai }\end{array}$ & $\begin{array}{l}\text { Kesesuaian dengan } \\
\text { indikator keterampilan } \\
\text { pemecahan masalah } \\
\text { yang ingin diukur }\end{array}$ \\
\hline 1 & 0,9 & 0,95 \\
\hline 2 & 0,75 & 0,8 \\
\hline 3 & 0,95 & 0,95 \\
\hline 4 & 0,8 & 0,9 \\
\hline
\end{tabular}

Tabel 2. Analisis Aiken untuk Aspek Konstruk

\begin{tabular}{|c|l|l|}
\hline \multirow{2}{*}{$\begin{array}{c}\text { Butir } \\
\text { Ke- }\end{array}$} & \begin{tabular}{l}
$|c|$ \\
\cline { 2 - 3 } \\
Penggunaan kalimat \\
tanya atau perintah \\
yang menuntut \\
jawaban terurai pada \\
soal
\end{tabular} & $\begin{array}{l}\text { Penggunaan } \\
\text { pedoman } \\
\text { penskoran yang } \\
\text { sangat jelas }\end{array}$ \\
\hline 1 & 0,9 & 0,95 \\
\hline 2 & 0,75 & 0,95 \\
\hline 3 & 0,95 & 0,95 \\
\hline 4 & 0,85 & 0,95 \\
\hline
\end{tabular}

Tabel 3. Analisis Aiken untuk Aspek Bahasa

\begin{tabular}{|c|c|c|c|}
\hline \multirow{2}{*}{$\begin{array}{c}\text { Butir } \\
\text { Ke- }\end{array}$} & $\begin{array}{l}\mid 3 \\
\text { Penggunaan } \\
\text { bahasa indonesia } \\
\text { yang baku dan } \\
\text { kesesuaian } \\
\text { dengan EYD }\end{array}$ & $\begin{array}{l}\text { Aspek } \\
\text { ambiguitas } \\
\text { pada } \\
\text { kalimat } \\
\text { soal }\end{array}$ & $\begin{array}{l}\text { Aspek ke } \\
\text { Komunik } \\
\text { atifan } \\
\text { kalimat }\end{array}$ \\
\hline 1 & 0,95 & 0,95 & 0,95 \\
\hline 2 & 0,95 & 0,95 & 0,9 \\
\hline 3 & 0,95 & 0,95 & 0,95 \\
\hline 4 & 0,95 & 0,95 & 0,95 \\
\hline
\end{tabular}

Berdasarkan Tabel 1, Tabel 2, Tabel 3 diketahui bahwa hasil validasi oleh ahli menunjukkan nilai validasi isi berdasarkan hasil analisis aiken terhadap aspek materi, konstruk, dan bahasa memiliki nilai pada rentang 0,75 sampai 0,95 yang berarti tes memiliki validasi yang tinggi bahkan sangat tinggi.

Setelah dilakukan proses review selanjutnya instrumen akan melalui tahap uji pendahuluan yang dilakukan kepada 30 orang siswa kelas XI yang telah mempelajari materi Dinamika rotasi dan Kesetimbangan benda tegar. Dari uji pendahuluan diperoleh estimasi waktu maksimal siswa dalam mengerjakan instrumen tes tersebut pada uji lapangan. Selain itu, percobaan pendahuluan (terbatas) untuk uji keterbacaan soal tes keterampilan pemecahan masalah kepada kelompok siswa yang telah ditentukan juga dilakukan dengan menggunakan metode wawancara kognitif (Tiruneh et al., 2016) untuk mengetahui kekurangan dari tes yang dikonstruksi dari segi keterbacaan oleh siswa. Hasil wawancara kognitif seperti disajikan pada tabel berikut : 
Tabel 4. Hasil Wawancara Kognitif

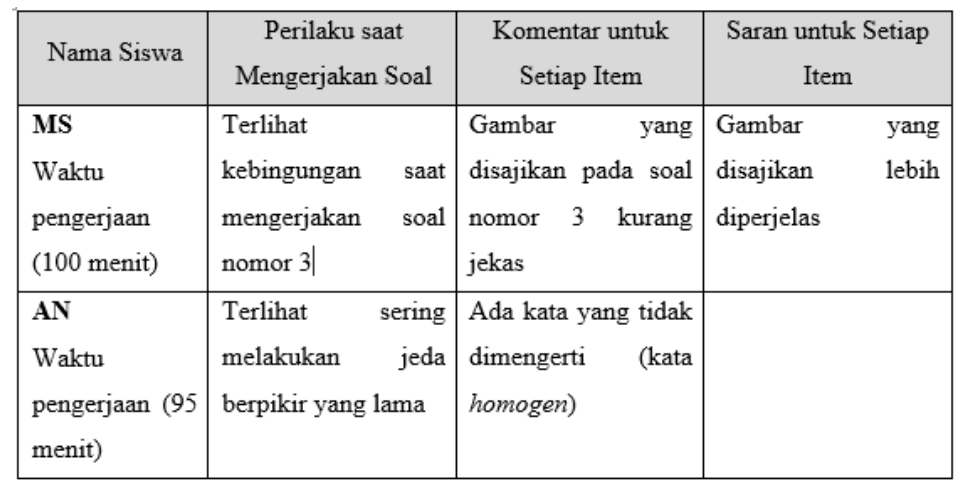

Uji lapangan dilakukan kepada 171 siswa SMA kelas XI IPA, dan diperoleh hasil pengerjaan dari tes keterampilan pemecahan masalah yang diujikan. Data dari hasil uji lapangan kemudian dianalisis dengan menggunakan teori respons butir untuk mengetahui karakteristik tes keterampilan pemecahan masalah dalam penelitian ini. Analisis IRT ini menggunakan bantuan software IRTPro, yaitu sebuah software yang dapat digunakan untuk membantu peneliti dalam menganalisis butir tes yang di konstruksi. Berdasarkan analisis terhadap kurva fungsi informasi total diketahui bahwa tes yang dikonstruksi lebih sesuai apabila dianalisis dengan menggunakan model respons butir partial credit model (PCM), hal ini karena puncak fungsi informasi PCM menunjukkan angka yang lebih tinggi dibandingkan dengan GPCM (Generalized Partial Credit Model) yaitu suatu bentuk umum dari PCM yang disebut sebagai fungsi respons kategori butir, sesuai dengan yang disebutkan oleh Baker (2001) bahwa uji fungsi informasi yang terbaik akan memiliki puncak pada skor cutoff.

Berdasarkan hasil analisis teori respons butir dengan menggunakan model respons butir PCM diperoleh karakteristik butir tes, yaitu tingkat kesukaran, daya pembeda, serta reliabilitas tes, seperti pada Gambar 1.

Kurva Karakteristik Total

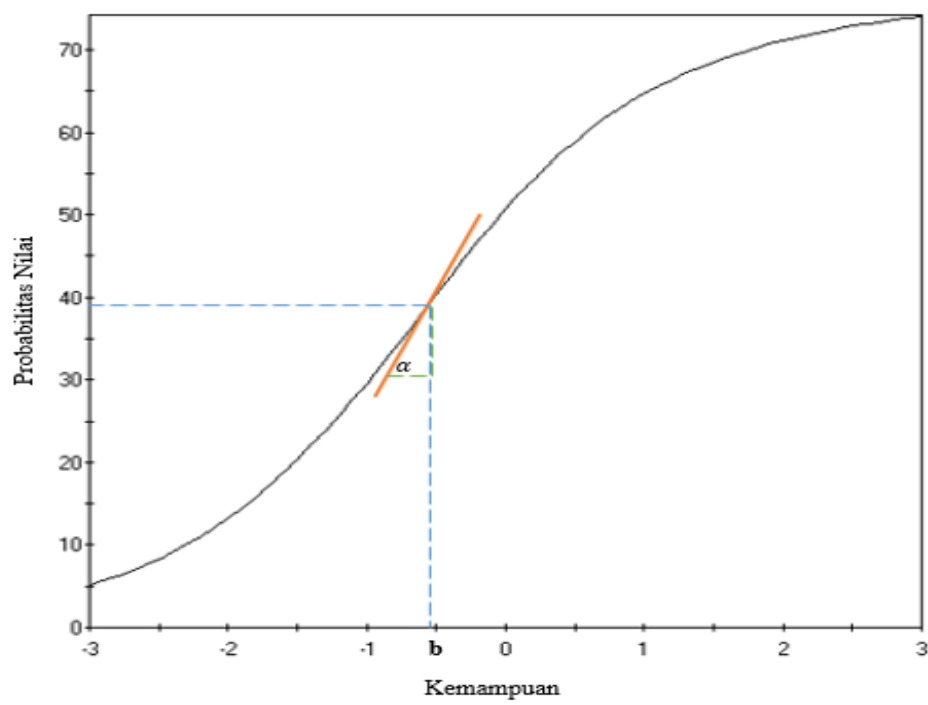

Gambar 1. Kurva Karakteristik Total

Berdasarkan Gambar 1. diketahui bahwa probabilitas 1 berada pada skor 74 dan probabilitas 0 berada pada skor 5, artinya probabilitas 0,5 berada di skor 39,5 pada kurva karakteristik total. Berdasarkan Gambar 4 dapat diketahui nilai $\mathrm{b}$ dengan cara menarik garis horizontal pada nilai probabilitas 0,5 sampai kurva karakteristik total. Kemudian garis vertikal dibuat tepat pada perpotongannya. Nilai yang ditunjukkan pada sumbu X merupakan nilai $b$ dari TCC. Nilai $b$ atau parameter tingkat kesukaran tes keterampilan pemecahan masalah berdasarkan kurva karakteristik total yaitu sebesar $-0,58$ atau dalam kategori tingkat kesukaran 
sedang. Sedangkan nilai a diperoleh dari kemiringan lereng kurva atau dapat diketahui dengan $\tan \alpha$. Berdasarkan kurva karakteristik total diperoleh kemiringan kurva sebesar $14^{0}$, sehingga $\tan \alpha=\tan 14^{0}=0,25$ artinya parameter daya pembeda (a) tes keterampilan pemecahan masalah sebesar 0,25 dalam kategori baik, hal ini sesuai dengan kriteria interpretasi baik yang disebutkan oleh Retnawati, H. (2014) bahwa STEM dikatakan baik jika memiliki $0<\mathrm{a}<2$ dan $-2<$ b $<2$.

Selain kategori parameter tingkat kesukaran tes, melalui analisis teori respons butir juga dapat diketahui hasil analisis parameter tingkat kesukaran (b) tiap butir yang dianalisis dari grafik kurva karakteristik butir. Kategori parameter tingkat kesukaran (b) dapat dilihat pada Tabel 5 Hasil analisis menunjukkan bahwa tingkat kesukaran tiap butir berada pada rentang mudah hingga sedang karena berada pada rentang -2 sampai +1 Parameter tingkat kesukaran (b) tiap butir dapat dilihat pada Tabel 5

Tabel 5. Parameter Tingkat Kesukaran Tiap Butir

\begin{tabular}{cccccccc}
\hline $\begin{array}{c}\text { Butir } \\
\text { Soal }\end{array}$ & (b) & $\begin{array}{c}\text { Butir } \\
\text { Soal }\end{array}$ & (b) & $\begin{array}{c}\text { Butir } \\
\text { Soal }\end{array}$ & (b) & $\underset{c}{\text { Butir }}$ & (b) \\
\hline 1 & $-0,41$ & $\mathbf{6}$ & $-1,24$ & $\mathbf{1 1}$ & $-0,45$ & $\mathbf{1 6}$ & $-0,65$ \\
2 & $-0,76$ & $\mathbf{7}$ & 0,43 & $\mathbf{1 2}$ & 0,46 & $\mathbf{1 7}$ & 0,36 \\
3 & $-1,30$ & $\mathbf{8}$ & $-1,70$ & $\mathbf{1 3}$ & $-1,46$ & $\mathbf{1 8}$ & 0,10 \\
4 & $-1,35$ & $\mathbf{9}$ & $-1,71$ & $\mathbf{1 4}$ & $-1,45$ & $\mathbf{1 9}$ & 0,53 \\
5 & $-0,56$ & $\mathbf{1 0}$ & $-0,72$ & $\mathbf{1 5}$ & $-0,93$ & $\mathbf{2 0}$ & 0,12 \\
\hline
\end{tabular}

Selain itu melalui analisis IRT juga dapat diketahui perpotongan antar kategori pada tiap butir yang menunjukkan tingkat kesukaran untuk mencapai kategori berikutnya, nilai perpotongan ini mempunyai arti bahwa peningkatan keterampilan responden untuk memberi respons kategori k ke kategori selanjutnya memiliki tingkat kesukaran (b). Hasil analisis perpotongan tiap kategori didapatkan bahwa peningkatan keterampilan partisipan untuk mencapai kategori skor selanjutnya memiliki tingkat kesukaran dari rentang sangat mudah sampai sangat sukar.

Secara umum, hasil analisis kurva untuk setiap butir tes disajikan pada Tabel 6.

Tabel 6. Hasil analisis kurva karakteristik butir

\begin{tabular}{|c|c|c|c|c|c|c|c|c|c|c|}
\hline \multirow{2}{*}{$\begin{array}{c}\text { Butir } \\
\text { ke- }\end{array}$} & \multicolumn{2}{|r|}{$\delta_{i 1}$} & \multicolumn{2}{|r|}{$\delta_{i 2}$} & \multicolumn{2}{|r|}{$\delta_{i 3}$} & \multicolumn{2}{|r|}{$\delta_{i 4}$} & \multicolumn{2}{|r|}{$\delta_{i 5}$} \\
\hline & $\theta$ & Probabilitas & $\boldsymbol{\theta}$ & Probabilitas & $\theta$ & Probabilitas & $\theta$ & Probabilitas & $\theta$ & Probabilitas \\
\hline 1 & \multicolumn{2}{|c|}{ Tidak ada perpotongan } & \multicolumn{2}{|c|}{ Tidak ada perpotongan } & $-0,4$ & 0,33 & 0,4 & 0,38 & \multirow{2}{*}{\multicolumn{2}{|c|}{$\begin{array}{l}\text { Tidak ada perpotongan } \\
\text { Tidak ada perpotongan }\end{array}$}} \\
\hline 2 & \multicolumn{2}{|c|}{ Tidak ada perpotongan } & $-1,1$ & 0,40 & $-0,0$ & 0,37 & 1,3 & 0,44 & & \\
\hline 3 & $-2,6$ & 0,37 & $-2,2$ & 0,36 & $-0,8$ & 0,48 & \multicolumn{2}{|c|}{ Tidak ada perpotongan } & \multicolumn{2}{|c|}{ Tidak ada perpotongan } \\
\hline 4 & $-1,4$ & 0,08 & $-2,1$ & 0,17 & $-2,7$ & 0,09 & 0,8 & 0,49 & \multicolumn{2}{|c|}{ Tidak ada perpotongan } \\
\hline 5 & \multicolumn{2}{|c|}{ Tidak ada perpotongan } & $-1,8$ & 0,045 & \multicolumn{2}{|c|}{ Tidak ada perpotongan } & $-0,8$ & 0,39 & 1,8 & 0,49 \\
\hline 6 & $-0,3$ & 0,015 & -3 & 0,05 & $-0,2$ & 0,16 & $-1,7$ & 0,07 & Tidak & la perpotongan \\
\hline 7 & 2,0 & 0,001 & $-1,8$ & 0,012 & $-0,2$ & 0,16 & 0,4 & 0,23 & Tidak & la perpotongan \\
\hline 8 & $-2,4$ & 0,44 & $-0,9$ & 0,43 & \multicolumn{2}{|c|}{ Tidak ada perpotongan } & \multicolumn{2}{|c|}{ Tidak ada perpotongan } & \multicolumn{2}{|c|}{ Tidak ada perpotongan } \\
\hline 9 & \multicolumn{2}{|c|}{ Tidak ada perpotongan } & $-1,9$ & 0,42 & 0,1 & 0,47 & \multicolumn{2}{|c|}{ Tidak ada perpotongan } & \multirow{2}{*}{\multicolumn{2}{|c|}{$\begin{array}{l}\text { Tidak ada perpotongan } \\
\text { Tidak ada perpotongan }\end{array}$}} \\
\hline 10 & 0,2 & 0,005 & \multicolumn{2}{|c|}{ Tidak ada perpotongan } & $-1,3$ & 0,33 & 1,3 & 0,49 & & \\
\hline 11 & 1,2 & 0001 & $-1,0$ & 0,06 & $-1,0$ & 0,06 & $-1,2$ & 0,04 & \multicolumn{2}{|c|}{ Tidak ada perpotongan } \\
\hline 12 & 0,3 & 0,35 & 0,2 & 0,29 & 0,8 & 0,29 & 12 & 0,34 & \multicolumn{2}{|c|}{ Tidak ada perpotongan } \\
\hline 13 & $-0,8$ & 0,016 & & & $-1,6$ & 0,38 & 0,1 & 0,48 & & la perpotongan \\
\hline 14 & \multicolumn{2}{|c|}{ Tidak ada perpotongan } & $-1,6$ & 0,45 & 1,0 & 0,48 & \multicolumn{2}{|c|}{ Tidak ada perpotongan } & \multicolumn{2}{|c|}{ Tidak ada perpotongan } \\
\hline 15 & $-0,3$ & 0,027 & $-2,6$ & 0,08 & $-0,6$ & 0,33 & -02 & 0,36 & \multicolumn{2}{|c|}{ Tidak ada perpotongan } \\
\hline 16 & $-0,7$ & 0,027 & 0,9 & 0,002 & $-1,2$ & 0,037 & $-0,9$ & 0,68 & $-2,1$ & 0,001 \\
\hline 17 & $-0,3$ & 0,21 & $-1,1$ & 0,23 & 1,2 & 0,37 & 1,6 & 0,36 & \multicolumn{2}{|c|}{ Tidak ada perpotongan } \\
\hline 18 & 0,7 & 0,06 & 1,6 & 0,006 & $-1,7$ & 0,003 & $-0,4$ & 0,08 & \multicolumn{2}{|c|}{ Tidak ada perpotongan } \\
\hline 19 & 0,7 & 0,23 & 1,1 & 0,166 & $-0,1$ & 0,08 & \multicolumn{2}{|c|}{ Tidak ada perpotongan } & \multirow{2}{*}{\multicolumn{2}{|c|}{$\begin{array}{l}\text { Tidak ada perpotongan } \\
\text { Tidak ada perpotongan }\end{array}$}} \\
\hline 20 & 1.5 & 0,002 & $-2,7$ & 0,005 & $-1,4$ & 0,05 & 1,9 & 0,49 & & \\
\hline
\end{tabular}


Hasil analisis PCM dan kurva karakteristik butir yang mengacu pada Retnawati, H. (2014) , sebagai contoh pada butir 1, 4, dan 7 sebagai berikut :

\section{Butir ke-1}

Butir pertama merupakan soal yang terdapat pada nomor soal 1 yang dikonstruksi berdasarkan indikator mengidentifikasi masalah berdasarkan konsep dasar kesetimbangan statis. Tingkat kesukaran butir ini sebesar $-0,41$ yang artinya butir pertama memiliki tingkat kesukaran yang tergolong sedang.

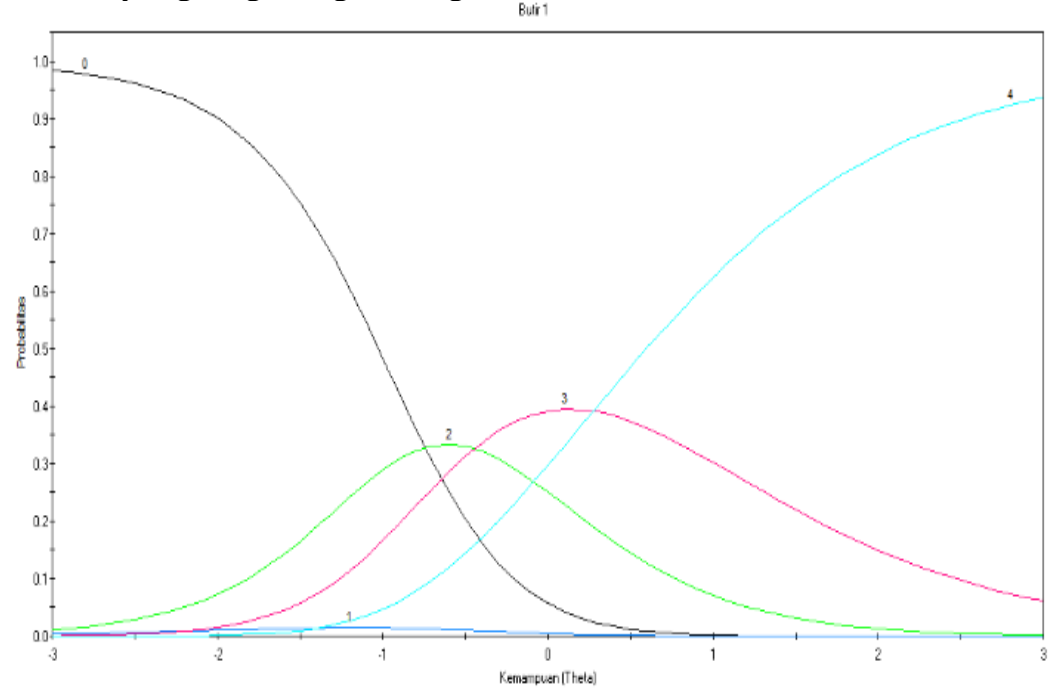

Keterangan warna :

$\begin{array}{ll}\text { Hitam } & \text { : Nilai 0 } \\ \text { Biru } & \text { : Nilai 1 } \\ \text { Hijau } & \text { : Nilai 2 } \\ \text { Merah muda } & \text { : Nilai 3 } \\ \text { Tosca } & \text { : Nilai 4 } \\ \text { Hijau Tua } & \text { : Nilai 5 }\end{array}$

\section{Gambar 2. Kurva Karakteristik Butir 1}

Selain itu, dari Gambar 2 dapat diketahui juga mengenai persimpangan atau perpotongan kategori atau tahap. Hal ini menunjukkan titik yang menjelaskan mengenai sifat laten antara dua kategori yang berurutan kurva respons berpotongan atau dikenal dengan parameter $\delta i j$. Parameter ini dapat dianalisis dengan mudah melalui grafik. Berdasarkan Gambar 2 dapat diketahui bahwa:

a. perpotongan garis pada kategori 0 dan $1\left(\delta_{11}\right)$ tidak ada perpotongan, hal ini menandakan bahwa peningkatan kemampuan responden untuk memberi respons jawaban 0 ke respons jawaban 1 tidak diketahui berdasarkan kurva.

b. Perpotongan garis pada kategori 1 dan $2\left(\delta_{12}\right)$ juga tidak ada perpotongan, hal ini menandakan bahwa peningkatan kemampuan responden untuk memberi respons jawaban 1 ke respons jawaban 2 tidak diketahui berdasarkan kurva. 
c. Perpotongan garis pada kategori 2 dan $3\left(\delta_{13}\right)$ berada pada theta $(\theta)=-0,4$ dengan probabilitas 0,33 , hal ini menandakan bahwa peningkatan kemampuan responden untuk memberi respons jawaban 2 ke respons jawaban 3 memiliki tingkat kesukaran sedang.

d. Perpotongan garis pada kategori 3 dan $4\left(\delta_{14}\right)$ berada pada theta $(\theta)=0,4$ dengan probabilitas 0,38 , hal ini menandakan bahwa peningkatan kemampuan responden untuk memberi respons jawaban 3 ke respons jawaban 4 memiliki tingkat kesukaran sedang.

\section{Butir Ke-4}

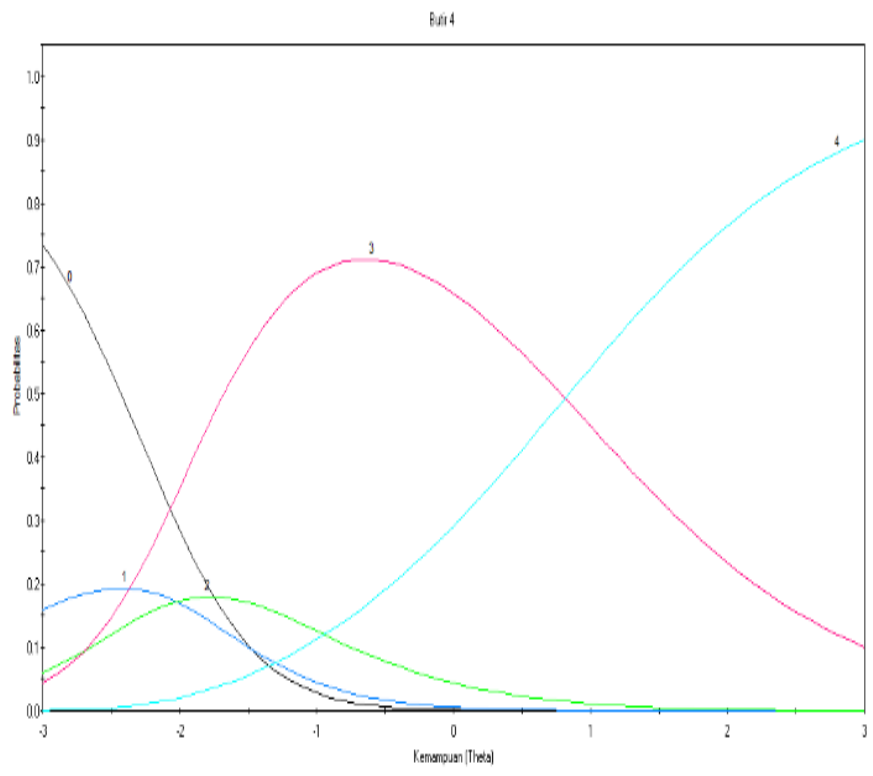

Gambar 3. Kurva Karakteristik Butir 4

Butir keempat merupakan soal yang terdapat pada nomor soal 1 yang dikonstruksi berdasarkan indikator melakukan perhitungan dengan menggunakan persamaan yang dipilih. Tingkat kesukaran butir ini sebesar -1.35 yang artinya butir keempat memiliki tingkat kesukaran yang tergolong mudah.

Berdasarkan Gambar 3 juga dapat diketahui informasi sebagai berikut :

a. perpotongan garis pada kategori 0 dan $1\left(\delta_{41}\right)$ berada pada theta $(\theta)=-1,4$ dengan probabilitas 0,08 . Hal ini menandakan bahwa peningkatan kemampuan responden untuk memberi respons jawaban 0 ke respons jawaban 1 memiliki tingkat kesukaran mudah

b. Perpotongan garis pada kategori 1 dan $2\left(\delta_{42}\right)$ berada pada theta $(\theta)=-2,1$ dengan probabilitas 0,17 . Hal ini menandakan bahwa peningkatan kemampuan responden untuk memberi respons jawaban 1 ke respons jawaban 2 memiliki tingkat kesukaran sangat mudah.

c. Perpotongan garis pada kategori 2 dan $3\left(\delta_{43}\right)$ berada pada theta $(\theta)=-2,7$ dengan probabilitas 0,09 . hal ini menandakan bahwa peningkatan kemampuan responden untuk memberi respons jawaban 2 ke respons jawaban 3 memiliki tingkat kesukaran sangat mudah. 
d. Perpotongan garis pada kategori 3 dan $4\left(\delta_{44}\right)$ berada pada theta $(\theta)=0,8$ dengan probabilitas 0,49 . Hal ini menandakan bahwa peningkatan kemampuan responden untuk memberi respons jawaban 3 ke respons jawaban 4 memiliki tingkat kesukaran sedang.

\section{Butir ke-7}

Butir ketujuh merupakan soal yang terdapat pada nomor soal 2 yang dikonstruksi berdasarkan indikator mengubah representasi visual kedalam deskripsi fisika terkait hukum kekekalan momentum sudut. Tingkat kesukaran butir ini sebesar -0,43 yang artinya butir ketujuh memiliki tingkat kesukaran yang tergolong sedang.

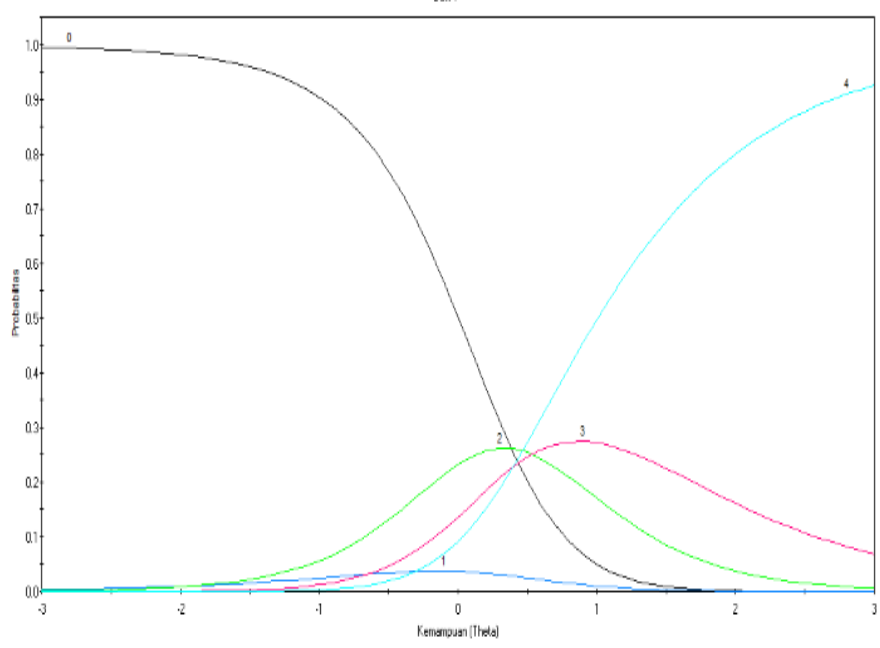

Gambar 4. Kurva Karakteristik Butir 7

Berdasarkan Gambar 4 dapat diketahui bahwa:

a. perpotongan garis pada kategori 0 dan $1\left(\delta_{71}\right)$ berada pada theta $(\theta)=2,0$ dengan probabilitas 0,001 . Hal ini menandakan bahwa peningkatan kemampuan responden untuk memberi respons jawaban 0 ke respons jawaban 1 memiliki tingkat kesukaran sukar.

b. Perpotongan garis pada kategori 1 dan $2\left(\delta_{72}\right)$ berada pada theta $(\theta)=-1,8$ dengan probabilitas 0,012 . Hal ini menandakan bahwa peningkatan kemampuan responden untuk memberi respons jawaban 1 ke respons jawaban 2 memiliki tingkat kesukaran mudah.

c. Perpotongan garis pada kategori 2 dan $3\left(\delta_{73}\right)$ berada pada theta $(\theta)=-0,2$ dengan probabilitas 0,16 . Hal ini menandakan bahwa peningkatan kemampuan responden untuk memberi respons jawaban 2 ke respons jawaban 3 memiliki tingkat kesukaran sedang.

d. Perpotongan garis pada kategori 3 dan $4\left(\delta_{74}\right)$ berada pada theta $(\theta)=0,4$ dengan probabilitas 0,23 . Hal ini menandakan bahwa peningkatan kemampuan responden untuk memberi respons jawaban 3 ke respons jawaban 4 memiliki tingkat kesukaran sedang.

Selanjutnya berdasarkan kurva fungsi informasi total diketahui bahwa puncak fungsi informasi total berada pada nilai 23,34 pada skala kemampuan atau theta $(\theta)-0,6$ dengan kesalahan pengukuran atau standard error sebesar 0,20 dengan perpotongan antara kurva 
fungsi informasi dengan kesalahan pengukuran atau standard error measurement (SEM) berada pada skala -2,30 sampai 1,10 seperti yang terlihat pada Gambar 5 .

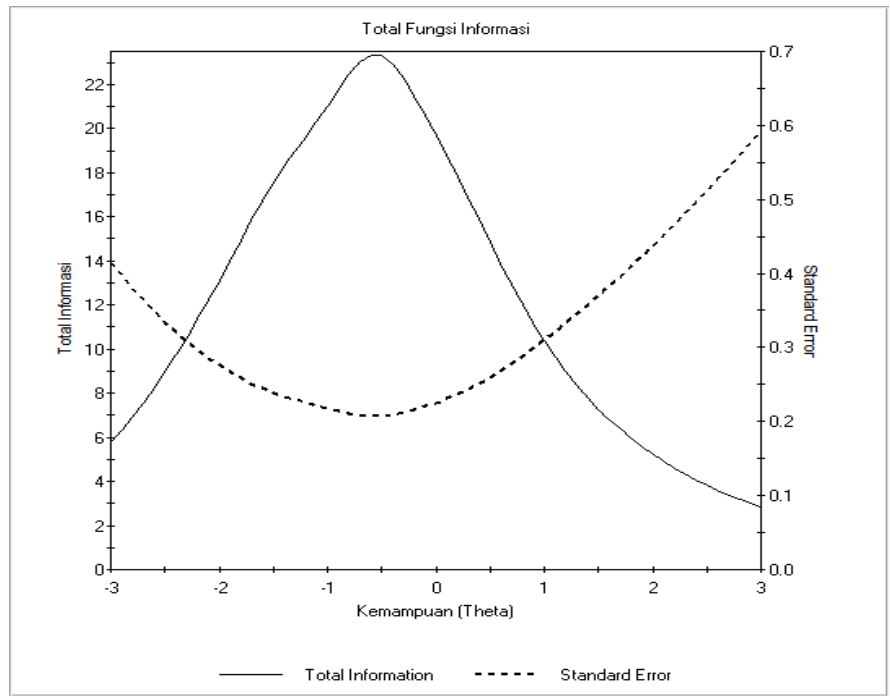

Gambar 5. Kurva Fungsi Informasi Total

Tes keterampilan pemecahan masalah ini reliabel untuk daerah pengukuran -2,30 sampai 1,10. Hal ini menunjukkan bahwa tes keterampilan pemecahan masalah pada materi Dinamika Rotasi dan Kesetimbangan Benda Tegar ini dapat dipergunakan dalam penilaian siswa yang memiliki kemampuan rendah hingga tinggi.

\section{KESIMPULAN}

Dari penelitian ini dapat dibuktikan bahwa kelebihan dari analisis teori respons butir (item response theory) selain dapat mengetahui karakteristik tes juga dapat mengetahui karakteristik dari setiap butir tes. Selain itu, dari penelitian ini dapat disimpulkan bahwa karakteristik soal yang dikonstruksi memiliki parameter tingkat kesukaran (b) yang baik karena nilai parameter tingkat kesukaran (b) yaitu $-0,58$ termasuk dalam kategori sedang. Parameter daya pembeda (a) bernilai 0,25 yang berarti berada pada rentang 0 sampai +2 sehingga dikategorikan tes memiliki parameter daya pembeda (a) yang baik. Puncak fungsi informasi total berada pada nilai 23,34 pada skala kemampuan atau theta $(\theta)-0,6$ dengan kesalahan pengukuran atau standard error sebesar 0,20 dengan perpotongan antara kurva fungsi informasi dengan kesalahan pengukuran atau standard error measurement (SEM) berada pada skala $-2,30$ sampai 1,10 . Sehingga, tes keterampilan pemecahan masalah ini reliabel untuk daerah pengukuran $-2,30$ sampai 1,10. Hal ini menunjukkan bahwa tes keterampilan pemecahan masalah pada materi Dinamika Rotasi dan Kesetimbangan Benda Tegar ini dapat dipergunakan dalam penilaian siswa yang memiliki kemampuan rendah hingga tinggi. 


\section{DAFTAR PUSTAKA}

Aiken, L. R. (1985). Three Coefficients for Analyzing the Reability and Validity of Ratings. Malibu: Pepperdine University.

Binkley, M 2012, 'Defining twenty-first century skills', Assesment and Teaching of 21st Century Skills, 17-64.

Baker, F. B. (2001). The Basic of Item Response Theory. United States: ERIC Clearinghouse on Assessment and Evaluation.

Barak, M. (2017). Science Teacher Education in the Twenty-First Century: a Pedagogical Framework for Technology-Integrated Social Constructivism. Research in Science Education, 47,(2).

Bolstad, R. (2011). Taking a Future Focus in Education - What Does It Mean? NZCER Working Paper. Wellington, New Zealand Council for Educational Research.

Bybee, R.W. \& Fuchs, B. (2006). Preparing the 21st Century Workforce: A New Reform in Science and Technology Education. Journal Of Research In Science Teaching , 43. 349-352.

Chrisnawati, HE. (2007). Pengaruh metode pembelajaran kooperatif tipe STAD terhadap kemampuan problem solving siswa SMK (teknik) swasta di Surakarta ditinjau dari motivasi belajar siswa. Journal MIPA, 17.

Crocker, Linda. M., \& Algina, J. (1986). Introduction to classical and modern test theory. New York: Holt, Rinehart and Winston.

Dewi, IN., Poedjiastoeti, S., Prahani, BK. (2017). ELSII Learning Model Based Local Wisdom To Improve Students' Problem-Solving Skills and Scientific Communication. International Journal of Education and Research. 5, (1).

Doctor, J., \& Heller. (2009). Robust assessment instrument for student problem solving. Proceedings of the NARST 2009 Annual Meeting, Garden Grove, California.

Hambleton, R.K., \& Jones, R.W. (1993). Comparison of Classical Test Theory and Item Response Theory and Their Applications to Test Development. Educational Measurement : Issues and Practice, 12(3), 38-47. DOI : https://doi.org/10.1111/j.1745-3992.1993.tb00543.x.

Hidayat, S.R., Setyadin, A.H., Kaniawati, I., Suhendi, E., Siahaan, P., Hermawan., Samsudin, A. (2017). Pengembangan Instrumen Tes Keterampilan Pemecahan Masalah pada Materi Getaran, Gelombang, dan Bunyi. Jurnal Penelitian \& Pengembangan Pendidikan Fisika, 3,(2).

Hung, W.J.D. \& Liu, R. (2008). Problem-based learning. Handbook of Research on Educational Communications and Technology, 3.

Retnawati, H. (2014). Teori Respons Butir dan Penerapannya. Yogyakarta: Nuha Medika.

Sarea, M. S., \& Hadi, S. (2015). Analisis Kualitas Soal Ujian Akhir Semester Mata Pelajaran Kimia SMA di Kabupaten Gowa. Jurnal Evaluasi Pendidikan, 3,(1), $35-43$.

Saavedra, A., Opfer, V. (2012) Teaching and learning 21st Century Skills: Lessons from the Learning Sciences. A Global Cities Education Network Report. New York, Asia Society.

Setiadi, Hari. (1998). Bank Soal yang Dikalibrasi dengan Konsep IRT Memecahkan Permasalahan Ujian-ujian Sistematik yang Diadakan pada Periode-periode Tertentu. Jurnal Kajian Dikbud IV (13). 
Sudaryono. (2011). Implementasi Teori Respons Butir pada Penilaian Hasil Belajar Sekolah. Jurnal Pendidikan dan Kebudayaan.

Tiruneh, D.T., Cock, M.D., Weldeslassie, A.G., Elen, J., Janssen, R. (2016). Measuring Critical Thinking in Physics: Development and Validation of a Critical Thinking Test in Electricity and Magnetism. International Journal of Science and Mathematics Education, 1-21.

Wagner, T. (2010) Overcoming The Global Achievement Gap. Cambridge, Mass, Harvard University.

Zubaidah, Siti. (2016). Keterampilan Abad Ke-21 : Keterampilan Yang Diajarkan Melalui Pembelajaran. Prosiding Seminar Nasional Pendidikan. Kalimantan Barat: Program Studi Pendidikan Biologi STKIP Persada Khatulistiwa Sintang 